\section{BENDING AND BONDING PROPERTIES OF MIXED-SPECIES GLUED LAMINATED TIMBER FROM MERPAUH, JELUTONG AND SESENDOK}

\author{
Wan Hazira Wan Mohamada, Norshariza Mohamad Bhkarib, \\ Zakiah Ahmadb*
}

aFaculty of Applied Sciences, Universiti Teknologi MARA Malaysia, 40450 Shah Alam, Selangor, Malaysia bFaculty of Civil Engineering, Universiti Teknologi MARA Malaysia, 40450 Shah Alam, Selangor, Malaysia
Article history

Received

12 March 2018

Received in revised form

16 January 2019

Accepted

15 May 2019

Published online

25 June 2019

*Corresponding author zakiah@salam.vitm.edu.my

\section{Graphical abstract}

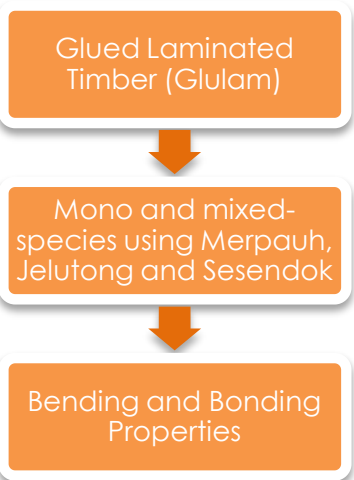

\begin{abstract}
This study investigates the bending and bonding performances of glved laminated timber beams manufactured using a combination of Malaysian lower and highergrade timber species. Two types of beams were prepared which were mono-species and mixed-species glulam. Mono-species glulam with uniform layup were fabricated using Merpauh, Jelutong and Sesendok. Mixed-species glulam with balanced layup were fabricated whereby Merpauh was positioned equally at the outer layers and either Jelutong or Sesendok were positioned at the inner layers. Three replicates of ten-layered glulam beams measuring $100 \mathrm{~mm}$ in width, $300 \mathrm{~mm}$ in depth and 6200 $\mathrm{mm}$ in length were manufactured according to MS758 for each mono and mixedspecies glulam. Bending, delamination and block shear tests were done on all the glulam beams. The results show that glulam manufactured from the combination of Sesendok and Merpauh obtained the highest bending properties and structural efficiency. In addition, the bonding performance at the interface between Sesendok-Merpauh lamellas proved to be excellent.
\end{abstract}

Keywords: Glulam, Mixed-species, Bending properties, Bonding properties, Delamination, Shear glue line

\begin{abstract}
Abstrak
Kajian ini dijalankan bagi melihat prestasi lenturan dan lekatan bagi rasuk kayu berperekat yang dihasilkan melalui gabungan kayu tropika Malaysia dari spesis kayu berkekuatan rendah dan kayu berkekuatan tinggi. Dalam kajian ini, dua jenis rasuk telah dibangunkan iaitu dari spesis tunggal sebagai sampel kawalan dan juga rasuk dari spesis campuran. Rasuk dari spesis tunggal dibina secara seragam dengan menggunakan spesis kayu Merpauh, Jelutong dan Sesendok. Rasuk spesis campuran pula dibina dengan kedudukan simetri di mana lapisan luar pada bahagian atas dan bawah rasuk adalah dari spesis kayu Merpauh manakala bahagian lapisan dalaman adalah dari spesis kayu Jelutong atau Sesendok. Bagi ujikaji makmal, tiga batang sampel dari setiap rasuk kayu berperekat dari spesis tunggal dan spesis campuran telah dibina. Sampel rasuk yang dibina ini terdiri daripada sepuluh lapisan kayu panel yang dilekatkan dengan keratan rentas rasuk berukuran $100 \mathrm{~mm}$ lebar dan $300 \mathrm{~mm}$ dalam. Panjang setiap rasuk pula berukuran $6200 \mathrm{~mm}$. Semua rasuk ini dibina berpandukan standard Malaysia, MS758. Ujikaji lenturan, delaminasi dan blok ricihan telah dijalankan ke atas semua sampel kajian. Keputusan kajian menunjukkan rasuk kayu berperekat dari spesis campuran Sesendok dan Merpauh telah memperolehi sifat lenturan yang tinggi dan mempunyai struktur rasuk yang lebih kuat berbanding dari sampel rasuk yang lain . Dalam kajian ini juga, prestasi lekatan bagi antara muka lapisan kayu bagi rasuk spesis campuran Sesendok dan Merpauh dibuktikan lebih baik.
\end{abstract}

Kata kunci: lapisan kayu berperekat, spesis kayu campuran, sifat lenturan, sifat lekatan, delaminasi, ricihan garisan lekatan 


\subsection{INTRODUCTION}

Glue laminated timber is defined in ASTM D3737 Standard Practice Establising Allowable Properties of Structural Glued Laminated Timber (Glulam) as "a material glued up from suitably selected and prepared pieces of wood whether in straight or curve form with the grain of all pieces essentially parallel to the longitudinal axis of the member." structural glulam is one of the oldest and established structural members and is widely used in developed country yet in Malaysia, the usage is only gaining acceptance in the construction industry. Recently, the Malaysia Timber Industry Board built an iconic glulam building using Resak and Keruing in Johor and it was recognized as the first building completed using glulam in Malaysia. Another recently completed project incorporating glulam is the Head Quarters of the Crops for the Future in Semenyih, Selangor.

One of the important characteristics in glulam manufacturing is that bonding of laminations produces beams with higher strength as compared to the strength of solid timber with the same dimensions [2]. This increase in strength is important because the quality of lamination is dependent on its magnitude. Laminating also allows the dispersion of timber defects throughout the length of the glulam member by redistributing stress of the defect through the clear wood of adjacent laminations [3]. In addition, laminating allows control over the positioning of different grades of timber within the glulam member cross-section. By placing the strongest timbers in the regions of greater stress e.g. the top and bottom of a bending member, the performance of the glulam members can be further enhanced [4].

Nearly any species or mixed-species combination can be used to manufacture glulam, provided its physical, mechanical and bonding properties are suitable and the timbers can be glved together [2]. Glulam members predominantly consist of softwood as they are the main source of structural timber, however hardwoods are slowly gaining importance in glulam production [5]. Mixed species combination commonly used in the United States include Douglas Fir (Pseudotsuga menziesii)-Larch (Larix occidetalis), Hemlock (Tsuga heterophylla)Douglas Fir and Spruce (Picea spp.)-Pine (Pinus spp.)-Fir-Red Maple (Acer spp.) [6]. Other mixed species combination studied by other reserachers includes Poplar (Populus $X$ euramaricana) Eucalyptus (Eucalyptus grandis) [4] as well as Sugi (Cryptomeria japonica) - Hinoki (Chamaecyparis obtuse) and Douglas Fir [7].

Although extensive research has been conducted on glulam [8-11], limited studies have been conducted to investigate the physical and mechanical properties of glulam using Malaysian hardwood timbers. Among the recent studies conducted include works done by Wan Mohamad et al. (2011), Wan Hazira et al. (2014) and Norshariza et al. (2014 and 2016]. Wan Mohamad et al. (2011) studied the bending strength of Resak and Keruing glulam and reported that the maximum bending capacity of both glulam beams were higher than the allowable bending strength stated in MS544 Part 3. This indicates that glulam beam using Malaysian timber is suitable as structural members. It was also found that glulam fabricated using lower density timber namely Merpauh (Strength Group 4) and Bintangor (Strength Group 5) was able to improve the strength of the timber through glulam technology (Wan Hazira et al., 2014). However, for timber with higher density (such as Strength Group 2 and Strength Group 3), the bending strength of glulam was at par with the bending strength of solid timber for that particular strength grade [14-15].

In Malaysia, heavy and medium hardwoods (SGI-SG4) are normally used as load bearing members. However not all of these species are suitable for glulam manufacturing. These higher grades, higher density timbers have difficult gluing characteristics and are expensive. On the other hand, light hardwoods (SG4-SG7) are mostly used for non-structural applications and do not represent efficient use of available timber. One way of fully utilizing and upgrading these timbers is by converting them into glulam and by combining with proven high quality timber species. The main objective of this study is to determine the effect of using Malaysian lower-grade species combined with higher-grade species on the bending and bonding properties of glulam beams.

\subsection{METHODOLOGY}

\subsection{Materials}

The species used to manufacture glulam beams were Merpauh (Swintonia spp.), Jelutong (Dyera spp.) and Sesendok (Endospermum spp.). The strength group and density of each timber species are shown in Table 1. The species selected is based on availability and strength groups namely SG4 for Merpauh, SG6 for Jelutong and SG7 for Sesendok. Phenol resorcinol formaldehyde (PRF) adhesive and hardener obtained from Dynea NZ Limited (Prefere 4001-2 and Prefere 5837) were used during end jointing and lamination.

Table 1 Strength group and density of timber species

\begin{tabular}{ccc}
\hline Timber species & $\begin{array}{c}\text { Strength Group } \\
\text { (SG) [16] }\end{array}$ & $\begin{array}{c}\text { Density }\left(\mathbf{k g} / \mathbf{m}^{\mathbf{3}}\right) \\
\text { [17] }\end{array}$ \\
\hline Merpauh & 4 & $640-880$ \\
\hline Jelutong & 6 & $415-495$ \\
\hline Sesendok & 7 & $305-655$ \\
\hline
\end{tabular}

\subsection{Specimen Preparation}

All timbers used for glulam manufacturing were graded into Hardwood Structural (HS) grade in accordance with MS1714. Two types of glulam beams were prepared; (i) mono-species with uniform layup and (ii) mixed-species with balanced 
layup (Figure 1). Three mono-species glulam were prepared using only Merpauh, Jelutong and Sesendok. For the mixed-species glulam, the positioning of the higher and lower strength grade timber in a beam was according to recommendations made in MS544 Part 3. The higher strength grade timber species i.e. Merpauh were equally positioned at the outer layers while the lower grade timber species, namely Jelutong and Sesendok were positioned at the inner layers of the beam. The depth of the higher-grade species was $40 \%$ of the total glulam beam depth. The lower grade species for the inner lamella was 2 to 3 grades lower than the outer lamella, as shown in Figure 1. The compositions of the mixed-species glulam were Jelutong-Merpauh and SesendokMerpauh. The glulam beam manufactured had dimensions of $6200 \mathrm{~mm}$ in length by $100 \mathrm{~mm}$ in width and $300 \mathrm{~mm}$ in depth, as shown in Figure 2.

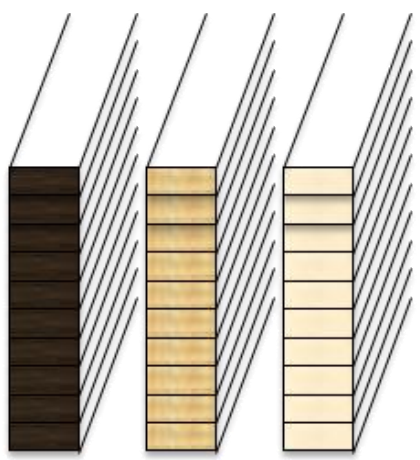

(a) Single-Species Glulam

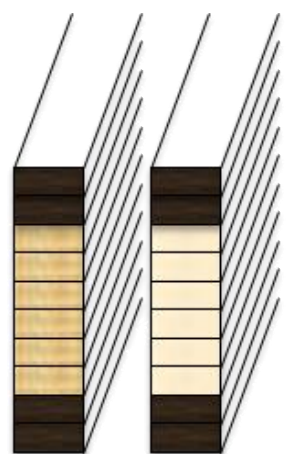

(b) Mixed-Species Glulam

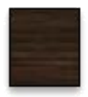

Merpauh

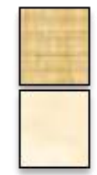

Jelutong

Sesendok

Figure 1 Beam composition of glulam

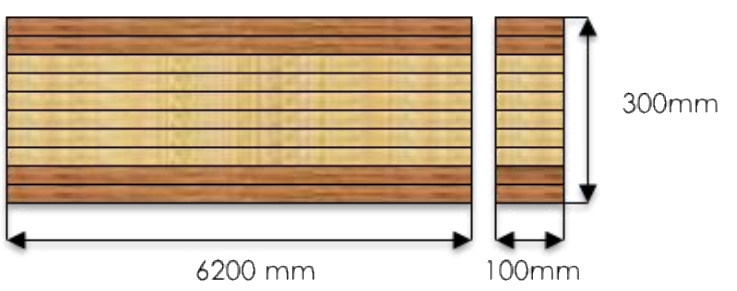

Figure 2 Dimension of glulam

\subsection{Test Method}

\subsubsection{Bending Test}

A three-point load bending test was set-up as shown Figure 3. The test was conducted according to ASTM D198. The bending strength, $S_{R}$ and modulus of elasticity, Ef were calculated according to the following equations. The actual bending test set-up is shown in Figure 4.

$$
\begin{aligned}
& \text { Modulus of rupture, } S_{R}=\frac{P_{\max } \times L}{b h^{2}} \\
& \text { Modulus of elasticity, } E_{f}=\frac{23 P L^{3}}{108 b h^{3} \Delta}
\end{aligned}
$$

where $P_{\max }$ is the maximum load borne by beam loaded to failure $(N), L$ is the span of the beam $(\mathrm{mm}), \mathrm{b}$ is the width of the beam $(\mathrm{mm}), \mathrm{h}$ is the depth of the beam $(\mathrm{mm})$, $a$ is the distance from reaction to nearest load point ( $1 / 3$ shear span) $(\mathrm{mm}), \mathrm{P}$ is the increment of applied load below proportional limit $(\mathrm{N})$ and $\Delta$ is the increment of deflectioin of beam's neutral axis measured at mid span.

300

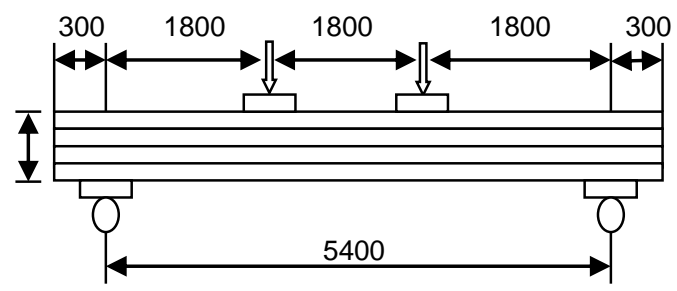

Figure 3 Schematic diagram of bending test set-up

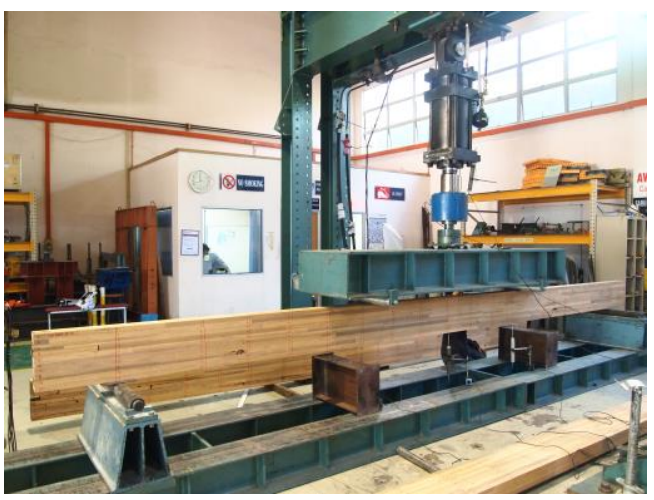

Figure 4 Actual bending test set-up

\subsubsection{Delamination Test}

Delamination test was conducted in accordance with MS758. Method A was applied because the adhesive used in this study to manufacture glulam beams was Type I Adhesive. The specimens for delamination test were extracted from the full cross section of the glulam beam and represented the glulam production run. The specimens were cut perpendicular to the grain of the glulam member and had dimensions of $75 \mathrm{~mm}$ in length (along the grain) by $100 \mathrm{~mm}$ in width and $300 \mathrm{~mm}$ in depth. Five replicates were tested for each glulam beams. The test specimens were subjected to two test cycles and an extra cycle was carried out for test specimens having a total delamination percentage of 5 and above. The lengths of the open glue lines on end grain surface for each test specimen were measured at the end of the test.

\subsubsection{Block Shear Test}

Block shear test on the glue lines were conducted according to MS758. The test specimens were taken from the full cross-section of the glulam beam and $1100 \mathrm{~mm}$ away from the edge of the beam. Specimens were cut perpendicular to the grain direction. All nine glue lines of each glulam beam specimens were tested. The dimension of the test specimens were $50 \mathrm{~mm}$ in length by $50 \mathrm{~mm}$ 
in width and $50 \mathrm{~mm}$ in depth, with the glue line at the center of the specimen. A $1000 \mathrm{kN}$ universal testing machine was used to test all the specimens. Constant load was applied and load readings was continuously detected and recorded up to the ultimate load, after at least 20 seconds. Shear strength were calculated and wood failure percentage were also determined.

\subsection{RESULTS AND DISCUSSION}

\subsection{Bending Properties of Glulam}

The bending properties of mono and mixedspecies glulam beams were analyzed in terms of modulus of rupture (bending strength) and modulus of elasticity. Three replicates were tested for each glulam beam and the mean and coefficient of variation (COV) was calculated. From Figure 5 and Figure 6, a clear difference between mixed Sesendok-Merpauh and others can be seen, both in the case of mono and mixedspecies glulam. Figure 5 shows that the highest modulus of elasticity, with respect to Merpauh was obtained using mixed Sesendok-Merpauh $(+35.73 \%)$ while mixed Jelutong-Merpauh showed lower increase (+20.10\%).

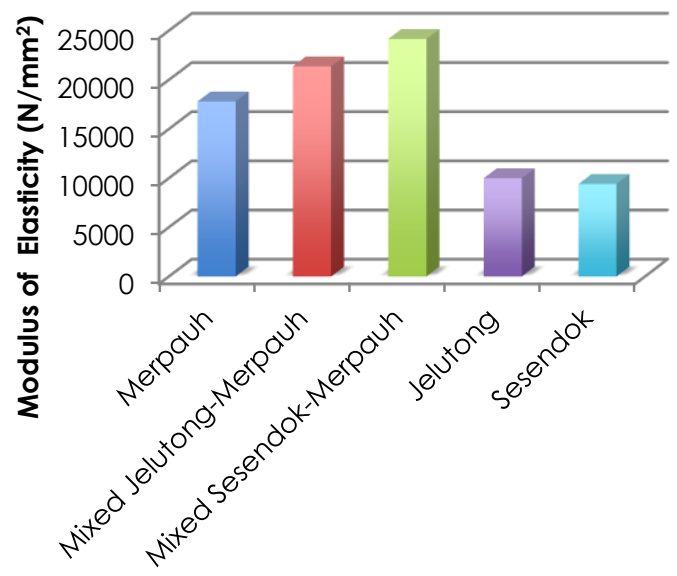

Figure 5 Modulus of elasticity in static bending
In the case of bending strength, as shown in Figure 6 , the maximum increase $(+36.50 \%)$ with respect to Merpauh was also found for mixed SesendokMerpauh glulam while mixed Jelutong-Merpauh showed lower increase (+18.68\%).

Out of the two mixed-species glulam, SesendokMerpauh obtained the highest bending properties whereby the percent increase of bending strength was $36.50 \%, 4.86 \%$ and $28.83 \%$ when compared against Merpauh, Jelutong and Sesendok, respectively. In addition, the percent increase of modulus of elasticity for Sesendok-Merpauh glulam when compared against Merpauh, Jelutong and Sesendok were 35.73\%, $141.84 \%$ and $156.75 \%$ respectively.

Table 2 shows the summary of the mean values for density, bending strength modulus of elasticity and structural efficiency for all glulam beams studied. The COV values are quite low indicating a low dispersion of mean values for both bending strength and modulus of elasticity.

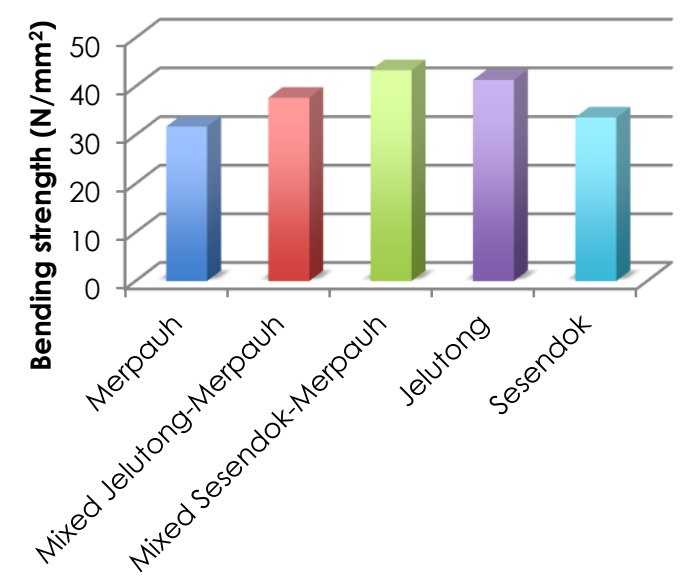

Figure 6 Bending strength

Figure 5 Load versus displacement curve

Table 2 Mean values, coefficient of variation and structural effciency of each species of beams for the bending characteristic

\begin{tabular}{|c|c|c|c|c|c|}
\hline Species & $\begin{array}{l}\text { Density } \\
\left(\mathrm{kg} / \mathrm{m}^{3}\right)\end{array}$ & $\begin{array}{l}\text { Bending strength } \\
\left(\mathrm{N} / \mathrm{mm}^{2}\right)\end{array}$ & $\begin{array}{c}\text { Structural } \\
\text { efficiency for } \\
\text { Bending strength }\end{array}$ & $\begin{array}{l}\text { Modulus of } \\
\text { elasticity } \\
\left(\mathrm{N} / \mathrm{mm}^{2}\right)\end{array}$ & $\begin{array}{l}\text { Structural } \\
\text { efficiency for } \\
\text { Modulus of } \\
\text { elasticity }\end{array}$ \\
\hline Merpauh & $8.69(0.66)$ & $31.75(7.15)^{c}$ & 0.04 & $17800(0.56)^{c}$ & 20.48 \\
\hline $\begin{array}{l}\text { Mixed Jelutong- } \\
\text { Merpauh }\end{array}$ & $626(1.88)$ & $37.68(2.44)^{a b}$ & 0.06 & $21370(8.56)^{b}$ & 34.14 \\
\hline $\begin{array}{l}\text { Mixed Sesendok- } \\
\text { Merpauh }\end{array}$ & $613(1.15)$ & $43.34(13.73)^{a}$ & 0.07 & $24160(8.49)^{a}$ & 39.41 \\
\hline Jelutong & 492 (2.39) & $41.33(1.4)^{a}$ & 0.08 & $9990(12.61)^{d}$ & 20.30 \\
\hline Sesendok & 487 (1.93) & $33.64(6.78)^{b c}$ & 0.07 & $9410(2.55)^{d}$ & 19.32 \\
\hline
\end{tabular}

Note: COV in parentheses. Same letters are not significant at 0.05 according to Duncan's Multiple Range Test. 
The load displacement curve under bending for all the beam studied is presented in Figure 7. Generally, all the beams had linear elastic behavior until failure occurred. The curve pattern indicated brittle behavior because all the beams failed abruptly after reaching ultimate load.
Mixed-species glulam obtained higher ultimate load compared to mono-species glulam, which indicates that mixed-species glulam beams are able to sustain bigger load when subjected to bending.

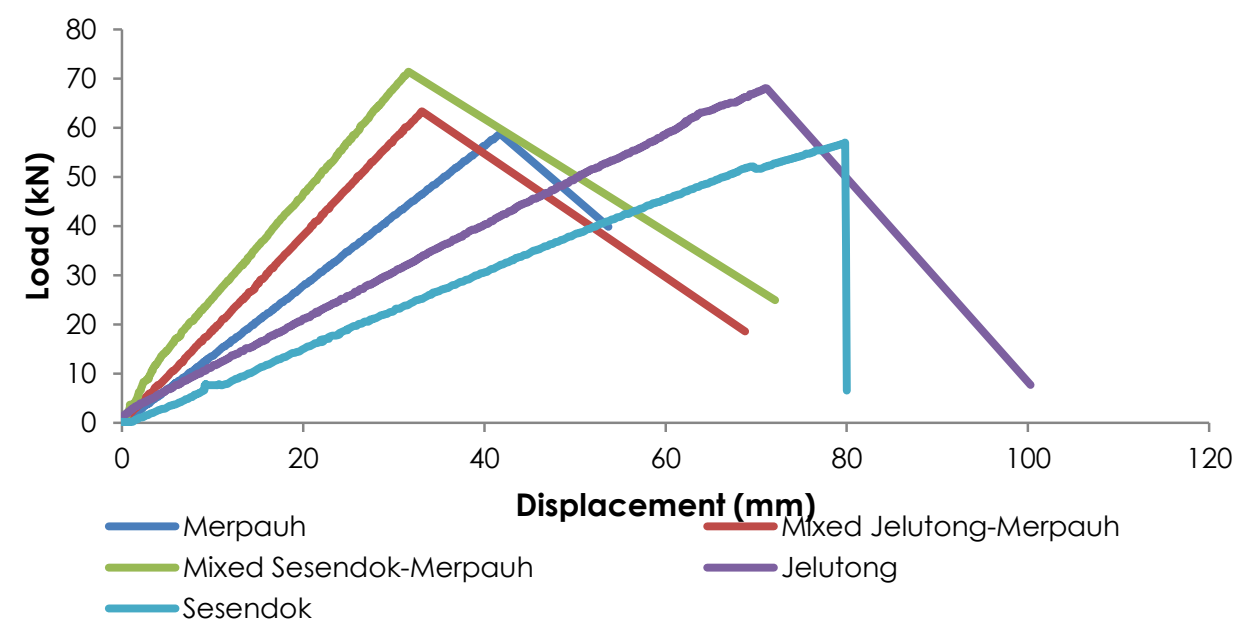

Figure 7 Load versus displacement curve

\subsection{Delamination in the Glue Line}

Figure 8 shows the average total delamination percentages after two cycles for all the glulam beams studied. The data indicates excellent quality of the glue lines in both mono and mixed species glulam beams. Eventhough Merpauh showed mixed results whereby one replicate exceeded the allowable maximum value set forth in MS758, the mean value of the average total delamination percentage for Merpauh was $4.3 \%$ which is below the maximum requirement value of $5 \%$. Low delamination percentage in the glve lines between Merpauh and Jelutong as well as Merpauh and Sesendok indicated non-existance of gluing problems at the interface between these wood species. This could be due to the similarity in shrinkage values for the species studied, as shown in Table 3.

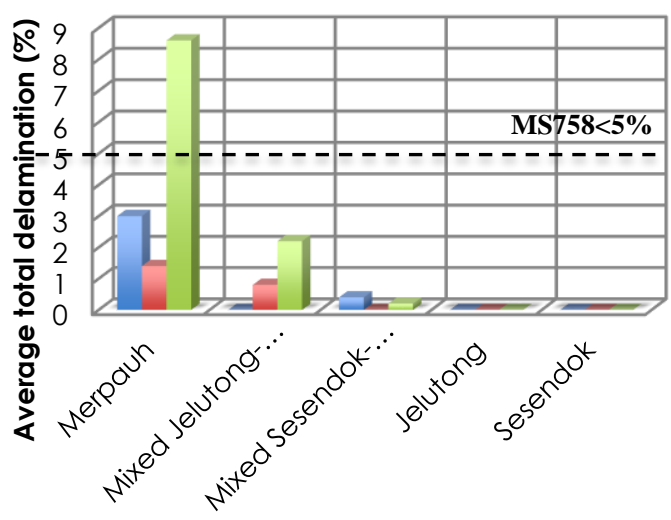

- Replicate 1 Replicate 2 Replicate 3
Table 3 Shrinkage percentages of Merpauh, Jelutong and Sesendok

\begin{tabular}{ccc}
\hline Species & \multicolumn{2}{c}{ Shrinkage percentage (\%) } \\
\cline { 2 - 3 } & Radial & Tangential \\
\hline $\begin{array}{c}\text { Merpauh } \\
\text { (S. Schwenkii) }\end{array}$ & 1.4 & 2 \\
\hline $\begin{array}{c}\text { Jelutong } \\
\text { (Dyera spp.) }\end{array}$ & 0.8 & 2 \\
\hline $\begin{array}{c}\text { Sesendok } \\
\text { (Endospermum spp.) }\end{array}$ & 1.2 & 1.3 \\
\hline Note: Data obtained from a dictionary of Malaysian Timbers [12].
\end{tabular}

\subsection{Shear Strength of Glue Line}

The average glue line shear strength and relative wood failure of all the glulam beams studied are summarized in Table 4. Generally, all the glulam beams fulfill the MS758 requirement which set forth a minimum of $6.0 \mathrm{~N} / \mathrm{mm}^{2}$ shear strength, while for lighter density timber, a shear strength of $4.0 \mathrm{~N} / \mathrm{mm}^{2}$ is acceptable provided the wood failure percentage is $100 \%$. For wood failure that did not reach $100 \%$, the values obtained were compared against the acceptance criteria stated in MS758. For shear strength of $11 \mathrm{~N} / \mathrm{mm}^{2}$, the minimum wood failure must be above $45 \%$ thus Merpauh, mixed Jelutong-Merpauh and mixed Sesendok-Merpauh met the requirement.

For shear strength of $8 \mathrm{~N} / \mathrm{mm}^{2}$, the minimum wood failure must be above $72 \%$ so both Jelutong and Sesendok met the requirement. This indicates good load carrying capability of the glue line in all the glulam studied as well as confirms the reliability of bonding found in the delamination tests.

Figure 8 Average total delamination after two initial cycles in percentage 
Table 4 Shear strength and relative wood failure

\begin{tabular}{|c|c|c|c|}
\hline Species & $\begin{array}{c}\text { Shear } \\
\text { Strength } \\
(\mathrm{N} / \mathrm{mm} 2)\end{array}$ & $\begin{array}{c}\text { Wood } \\
\text { Failure } \\
(\%)\end{array}$ & Criteria \\
\hline Merpauh & $\begin{array}{c}16.56 \\
(12.51)\end{array}$ & 80.86 & Met \\
\hline $\begin{array}{c}\text { Mixed } \\
\text { Jelutong- } \\
\text { Merpauh }\end{array}$ & $\begin{array}{c}10.36 \\
(35.06)\end{array}$ & 77.13 & Met \\
\hline $\begin{array}{c}\text { Mixed } \\
\text { Sesendok- } \\
\text { Merpauh }\end{array}$ & $\begin{array}{c}14.29 \\
(22.39)\end{array}$ & 88.68 & Met \\
\hline Jelutong & $8.07(7.33)$ & 85.81 & Met \\
\hline Sesendok & 9.56 (15.27) & 77.13 & Met \\
\hline
\end{tabular}

\subsection{CONCLUSION}

For all the glulam beams studied, mixed species beams showed higher bending properties as well as structural efficiency than those constructed entirely from Merpauh, Jelutong or Sesendok. The best bending performance between mixed species glulam is the combination of Sesendok and Merpauh. In addition, the excellent quality of the glue lines between laminates also contributed to the performance of the glulam beams. The results obtained from this study confirm the possibility of producing high structural efficiency glulam beams by combining two different timber species.

\section{Acknowledgement}

Malaysia Timber Industry Board (MTIB) financially supported the work reported here. We wish to thank the technicians of Civil Engineering Faculty, Universiti Teknologi MARA (UiTM) and Loji Pengeringan Tanor MTIB, Konsortium PEKA Sdn Bhd for their assistance and support.

\section{References}

[1] ASTM D3737. Standard Practice Establishing Allowable Properties of Structural Glued Laminated Timber (Glulam).

[2] Moody, R. C. and Hernandez, R. 1997. Glued Laminated Timber. Engineered Wood Products - A Guide for Specifiers, Designers and Users, S. Smulski, Ed. (Madison WI, PFS Research Foundation). 1-1-1-39.

[3] Castro, G. and Paganini, F. 2003. Mixed Glued Laminated Timber of Poplar and Eucalyptus Grandis Clones. Holz als Roh-und Werkstoff. 291-298.
[4] Falk, R. H. and Colling, F. 1995. Laminating Effects in Glued-laminated Timber Beams. Journal of Structural Engineering. 1857-1863.

[5] Aicher, S. and Stapf, G. 2014. Glulam from European White Oak: Finger-joint Influence on Bending Size Effect. Materials and Joints in Timber Structure, Aicher, S., Reinhardt H. W., Garrecht, H., Eds. (RILEM Bookseries, Vol.9 Springer Dordrecht).

[6] Janowiak, J. 1997. Red Maple Lumber Resources for Glued-laminated Timber Beams. Forest Products Journal. 47(4): 55-64.

[7] Hayashi, T. and Miyatake, A. 2015. Recent Research and Development on Sugi (Japanese Cedar) Structural Glued Laminated Timber. Journal of Wood Fibre. 61 (4): 337-342.

[8] Jun Jae Lee, Joo Saeng Park, Kwang Mo Kim, Jung Kwon Oh 2005. Prediction of Bending Properties for Structural Glulam using Optimized Distributions of Knot Characteristics and Laminar MOE. J. Wood Sci. 51: 640647.

[9] Herawati E., Massijaya, M. Y.. Nugroho, N. 2010. Performance of Glued-laminated Beams made from Small Diameter Fast-growing Tree Species. Journal of Biological Sciences. 10(1): 37-42.

[10] Massimo Del Senno, Franco Paganini, Mayriziu Piazza, Roberto Tomesi 2003. Investigation on Failure Behavior of Mixed-species Glued Laminated Timber Beams. Agricultural Engineering Conference (AEI) 2003.

[11] Rahma Nur Komariah, Yusuf Sudo Hadi, Muh Yusram Massijaya, Jajang Suryana 2015. Physical-mechanical Properties of Glued Laminated Timber Made from Tropical Small-diameter Logs Grown in Indonesia. J. Korean Wood Sci. Technol. 43(2): 156-167.

[12] Wan Mohamad, W. H. Razlan, M. A., Ahmad, Z. 2011. Bending Strength Properties of Glved Laminated Timber from Selected Malaysian Hardwood Timber. Int. J. Civ. Environ. Eng. 11 (4): 7-12.

[13] Wan Hazira, W. M., Zakiah, A., Ashari A. J. 2014. Bending Strength of Glulam from Selected Malaysian Hardwood Timber. Advanced Material Research. 879: 237-244.

[14] Norshariza, M. B. Ahmad, Z., Abu-Bakar, A. and Tahir, P. 2014. Structural Behaviour of Kekatong Glued Laminated Timber Railway Sleepers Under Sleepers Static Performance Test. The 4th International Conference on Green Building, Materials and Civil Engineering (GBMCE) 2014. 45-49.

[15] Norshariza, M. B., Ahmad, Z., Abu-Bakar, A. and Tahir, P. 2016. Assessment in Bending and Shear Strength of Glued Laminated Timber Using Selected Malaysian Tropical Hardwood as Alternative to Timber Railway Sleepers. J. Teknol. 78(5-5): 111-117.

[16] MS544: Part3:2001. Code of Practice for Structural Use of Timber: Part 3: Permissible Stress Design of Glued Laminated Timber.

[17] A Dictionary of Malaysian Timbers. 2002. Wong, T. M. Revised by Lim, S. C. and Chung, R. C. K. Forest Research Institute Malaysia (Malayan Forest Records; No 30).

[18] MS1714: 2003 Specification of Visual Strength Grading of Tropical Hardwood Timber.

[19] MS758: 2001. Glued Laminated Timber. Performance Requirements and Minimum Production Requirements.

[20] ASTM D198. Standard Test Methods of Static Tests of Lumber in Structural Sizes. 